\title{
Retraction Note: Hsa-miR-623 suppresses tumor progression in human lung adenocarcinoma
}

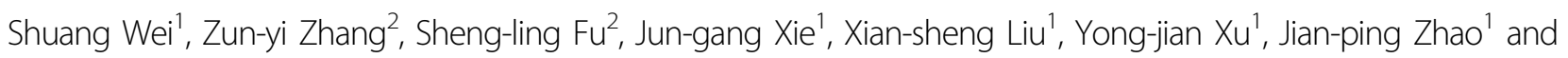
Wei-ning Xiong ${ }^{1}$

Retraction Note to: Cell Death and Disease (2016) 7: e2388 https://doi.org/10.1038/cddis.2016.260 published online 29 Sept 2016

The authors have retracted the article [Hsa-miR623 suppresses tumor progression in human lung adenocarcinoma, Cell Death \& Disease volume 7, page e2388 (2016), https://doi.org/10.1038/cddis.2016.260] because it has recently come to their attention that the A549 cells used in this research were contaminated with Hela cells, which may have altered the outcome of their experiment. The conclusions of this article are therefore unreliable. All authors agree to this retraction.

Published online: 25 January 2019

Correspondence: Jian-ping Zhao (zhaojp88@126.com) or

Wei-ning Xiong (xiongweining@tjh.tjmu.edu.cn)

${ }^{1}$ Department of Respiratory and Critical Care Medicine, Key Laboratory of

Pulmonary Diseases of Health Ministry, Key Cite of National Clinical Research

Center for Respiratory Disease, Tongji Hospital, Tongji Medical College

Huazhong University of Science and Technology, 1095 Jie Fang Avenue,

430030 Wuhan, China

2Department of Surgery, Tongji Hospital, Tongji Medical College Huazhong

University of Science and Technology, 1095 Jie Fang Da Dao, 430030 Wuhan,

China

These authors contributed equally: Shuang Wei, Zun-yi Zhang

() The Author(s) 2019

(c) (i) Open Access This article is licensed under a Creative Commons Attribution 4.0 International License, which permits use, sharing, adaptation, distribution and reproduction BY in any medium or format, as long as you give appropriate credit to the original author(s) and the source, provide a link to the Creative Commons license, and indicate if changes were made. The images or other third party material in this article are included in the article's Creative Commons license, unless indicated otherwise in a credit line to the material. If material is not included in the article's Creative Commons license and your intended use is not permitted by statutory regulation or exceeds the permitted use, you will need to obtain permission directly from the copyright holder. To view a copy of this license, visit http://creativecommons.org/licenses/by/4.0/. 